\title{
Human chorionic gonadotropin promotes cell proliferation through the activation of c-Met in gastric cancer cells
}

\author{
RUI ZHAO ${ }^{1 *}$, TONGTONG ZHANG ${ }^{2 *}$, WEIDONG XI ${ }^{3}$, XIAOBIN SUN ${ }^{3}$, \\ LINGXIAO ZHOU $^{1}$, YUANBIAO GUO ${ }^{2}, \mathrm{CONG} \mathrm{ZHAO}^{3}$ and $\mathrm{YU} \mathrm{BAO}^{1}$ \\ ${ }^{1}$ Department of Endoscopy Center, Sichuan Cancer Hospital, Chengdu, Sichuan 610041; ${ }^{2}$ Medical Research Center and \\ ${ }^{3}$ Department of Gastroenterology, The Third People's Hospital of Chengdu, Chengdu, Sichuan 610031, P.R. China
}

Received October 26, 2015; Accepted June 15, 2018

DOI: $10.3892 / \mathrm{ol} .2018 .9215$

\begin{abstract}
Hormones and their receptors affect the development process of gastric cancer. Previous studies have revealed that human chorionic gonadotropin (hCG) is expressed in gastric cancer tissue. However, the mechanism by which hCG exerts its effects on gastric cancer cells had not been reported. In the present study, the expression of hCG and its receptor was detected in gastric cancer tissues and para-carcinoma tissues of 62 patients with gastric carcinoma. Following the treatment of gastric cancer cells SGC-7901 with hCG, a cell counting kit- 8 assay, flow cytometry, a colony formation assay and a xenograft tumor model in nude mice were used to detect the effect of hCG on cell proliferation; and the expression of c-Met was determined by western blot analysis. The expression of hCG and its receptor were significantly higher in gastric cancer tissues compared with that of the matched para-carcinoma tissue $(\mathrm{P}<0.01)$. Proliferation of SGC-7901 cells treated with hCG was significant higher and the number of cells at the $\mathrm{G}_{2} / \mathrm{M}$ phase of the cell cycle increased compared with the control cells. Hepatocyte growth factor transmembrane protein receptor expression was increased in hCG-treated cells compared with the control cells, which relies on the protein kinase A signaling pathway. The present study revealed the potential function of hCG in the development of gastric cancer,
\end{abstract}

Correspondence to: $\mathrm{Dr} \mathrm{Yu}$ Bao, Department of Endoscopy Center, Sichuan Cancer Hospital, 55 South Renmin Road, Chengdu, Sichuan 610041, P.R. China

E-mail: baoyu514@163.com

Professor Cong Zhao, Department of Gastroenterology, The Third People's Hospital of Chengdu, 82 Quinglong Street, Chengdu, Sichuan 610031, P.R. China

E-mail: czhao0050@sohu.com

*Contributed equally

Key words: human chorionic gonadotropin, gastric cancer, proliferation, hepatocyte growth factor transmembrane protein receptor suggesting that hCG may be a molecular marker and potential drug target in gastric cancer.

\section{Introduction}

In its physiological state, human chorionic gonadotropin (hCG) is a type of growth factor, and an essential signaling molecule in the process of embryonic development, which stimulates the proliferation and differentiation of ovarian epidermal cells and controls the growth of follicle and corpus luteum formation (1). Additionally, one previous study (2) revealed that hCG is able to promote the expression of other growth factors, including estrogen in ovarian tissue and hepatocyte growth factor (HGF), and regulates cell division, morphology and cell apoptosis $(3,4)$. hCG is associated with numerous tumor-associated genes; for example, hCG regulates tumor suppressor genes and oncogenes in a dose-dependent manner including tumor protein p53, cyclin-dependent kinase inhibitor p21 ${ }^{\mathrm{WAF} 1 / \mathrm{Cip} 1}$, c-Fos, c-Jun and c-Myc (5-10). hCG is likely to affect cell proliferation and differentiation through growth factors or cancer genes, including that it induces the expression of cancer genes c-Myc, c-Jun and inhibin, in addition to affecting the differentiation of udder cells (11). hCG is also able to stimulate the growth of Kaposi's sarcoma cell (12).

Gastric cancer is a type of complex tumor that involves polygenes, multiple stages and migration $(13,14)$. Hormones, oncogenes, tumor suppressor genes and growth factors are involved in the process in different ways to varying degrees and at different stages (15). Although there is a lot of evidence demonstrating that hCG has a strong association with the differentiation and metastasis of gastric cancer cells $(16,17)$, its mechanism in gastric cancer remains unclear. Therefore, an in-depth study of the biological effect of hCG in gastric cancer will broaden current understanding of the development process of gastric cancer and help to develop earlier and more effective methods of endocrine therapy.

Through number of gastric cancer-associated genes, the overexpression of HGF transmembrane protein receptor (c-Met) gene exerts effects throughout the whole process of occurrence, development and outcome of gastric cancer. c-Met is a proto-oncogene coding receptor with tyrosine kinase activity (18). Additionally, c-Met is highly expressed in epithelial cells (19). HGF mainly regulates cell migration 
through c-Met in normal cells, however, in the process of cellular oncogenesis, it serves a critical role in tumor growth and evolution (18). Studies have revealed that c-Met is associated with the occurrence, metastasis and prognosis of gastric cancer $(18,20,21)$. At present, it is generally believed that it the presence of c-Met in the process of gastric cancer formation that results in gastric cancer differentiating into two cell types: The intestinal and the diffuse types (21).

In order to investigate the function of hCG in gastric cancer, the expression of $\mathrm{hCG}$ and its receptor were detected in gastric cancer tissue, and by stimulating the gastric cancer cell line SGC-7901 with hCG, the effect of hCG on the proliferation of gastric cancer cells was examined Furthermore by measuring the expression of the gastric cancer associated gene c-Met, the present study aimed to reveal the molecular mechanism of $\mathrm{hCG}$ in gastric cancer.

\section{Materials and methods}

Patients. The paraffin-embedded tissue samples of gastric cancer and para-carcinoma tissue from 62 patients (30 males and 32 females), aged from 38 to 82 years old (median age, 60 years old), were collected from Sichuan Cancer Hospital (Chengdu, China) diagnosed with gastric carcinoma between January 2010 to December 2012 at Sichuan Cancer Hospital, which were prepared for immunohistochemical detection. The staging of cancer was determined according to the tumor-node-metastasis (TNM) classification, using the American Joint Committee on Cancer (AJCC) recommendations (22). The present study was approved by the Institutional Review Board of the Sichuan Cancer Hospital and written informed consent was obtained from all patients prior to the study.

Immunohistochemical staining. Gastric cancer tissues were collected during surgery and fixed in $10 \%$ formalin for $24 \mathrm{~h}$ at $18^{\circ} \mathrm{C}$, prior to paraffin embedding. Paraffin sections (4- $\mu \mathrm{m}$ thick) of gastric cancer tissues were mounted on silanized slides, dewaxed at $65^{\circ} \mathrm{C}$ for $1 \mathrm{~h}$, deparaffinized with xylene at room temperature for $5 \mathrm{~min}$ and rehydrated using ethanol (100, $100,95,85,75$ and $75 \%$ ethanol, $3 \mathrm{~min}$ at room temperature). Following washing with PBS for $3 \mathrm{~min}$ at room temperature, endogenous enzymes were removed using $0.3 \%$ hydrogen peroxide/methanol solution at $37^{\circ} \mathrm{C}$ for $15 \mathrm{~min}$, followed by washing with PBS and drying. A total of $10 \%$ bovine serum albumin (BSA; Merck KGaA, Darmstadt, Germany) was added to block nonspecific binding sites at $37^{\circ} \mathrm{C}$ for $15 \mathrm{~min}$. Primary antibodies against (dilution, 1:50; cat no. C8534; Sigma-Aldrich, Merck KGaA, Darmstadt, Germany,) or hCG receptor (hCGR; dilution, 1:400; cat no. ab204950; Abcam, Cambridge, UK) were applied overnight at $4^{\circ} \mathrm{C}$. Following washing three times in PBS for $3 \mathrm{~min}$ at room temperature, immunodetection was performed using a labeled polymer horseradish peroxidase mouse antibody (cat no. SC-51948; dilution, 1:100; Santa Cruz Biotechnology, Inc., Dallas, TX, USA) incubated for $10 \mathrm{~min}$ at room temperature. Slides were subsequently washed with PBS for 3 min at room temperature, visualized with 3,3'-diaminobenzidine for $10 \mathrm{~min}$ and counterstained with Mayer's hematoxylin for $10 \mathrm{~min}$ at room temperature. The expression intensity of the target proteins in the tissues was determined by the positive cell number and staining intensity. The expression of hCG and its receptor in gastric cancer tissue and para-carcinoma tissue was then compared.

Cell culture and treatment. Gastric cancer cell line SGC-7901 was acquired from Shanghai Cell Bank (Shanghai, China) and was maintained in RPMI-1640 medium (Pierce; Thermo Fisher Scientific, Inc., Waltham, MA, USA) containing 10\% fetal bovine serum (FBS; Gibco; Thermo Fisher Scientific, Inc.) at $37^{\circ} \mathrm{C}$ and $5 \% \mathrm{CO}_{2}$ in a saturated humidity cultivation box. To study the effect of hCG on cancer cell proliferation, SGC-7901 cells were treated at $37^{\circ} \mathrm{C}$ for 5 days with hCG at the logarithmic phase using 0.09 and $0.89 \mathrm{IU} / \mathrm{ml} \mathrm{hCG}$, and the cells were divided into three groups: A control group (treated with PBS), a $0.09 \mathrm{IU} / \mathrm{ml}$ hCG-treated group and a $0.89 \mathrm{IU} / \mathrm{ml}$ hCG-treated group. To study the effects of blocking the protein kinase A (PKA) signaling pathway on the function of hCG, cAMP dependent protein kinase peptide inhibitor (PKAI) (Promega Corporation, Madison, WI, USA) was used for the specific binding of PKA 5-24 amino acids. A total of $10 \mu \mathrm{mol} / 1$ PKAI was added to serum free cultured SGC-7901 cells treated with 0 and $0.09 \mathrm{IU} / \mathrm{ml}$ hCG, and hCG-only treatment was used as the control.

Cell proliferation curve using cell counting kit-8 (CCK-8). SGC-7901 cells at a density of $2 \times 10^{3}$ per well in 96 -well plates were cultured for 5 days with hCG at concentrations of $0,0.09$ and $0.89 \mathrm{IU} / \mathrm{ml}$, and equal amounts of PBS were added to the control group. Experiments were performed in triplicate in serum-free RPMI-1640 medium at $37^{\circ} \mathrm{C}$ and $5 \% \mathrm{CO}_{2}$. CCK-8 (Dojindo Molecular Technologies, Inc., Kumamoto, Japan) was added to make up a final concentration of $10 \%$ and incubated with the cells at $37^{\circ} \mathrm{C}$ for $2 \mathrm{~h}$. Absorbance was measured at $450 \mathrm{~nm}$ using a plate reader (American Stat Fax-2100). An average of three repeats were performed to obtain the SGC-7901 cell proliferation curve of cells treated with hCG at days 1,2, 3, 4 and 5 post-treatment.

Cell cycle analysis by flow cytometry. Cells at a density of $2.5 \times 10^{5}$ cells/well were distributed into 6 -well plates and subjected to incubation for $48 \mathrm{~h}$. RPMI-1640 medium supplemented with $10 \%$ FBS was used for cell culture and incubation was performed at $37^{\circ} \mathrm{C}$ in an atmosphere of $5 \% \mathrm{CO}_{2}$. The medium was then replaced with fresh RPMI-1640 medium containing fisetin $(15 \mu \mathrm{M})$ in DMSO. Following $48 \mathrm{~h}$ incubation at $37^{\circ} \mathrm{C}$, the cells were subjected to trypsinization and subsequent washing with cold PBS. The cells were then fixed with $70 \%$ ethyl alcohol at $4^{\circ} \mathrm{C}$ for at least $4 \mathrm{~h}$, followed by addition of $20 \mu \mathrm{l}$ RNase (Thermo Fisher Scientific,) and $20 \mu \mathrm{l}$ PI (Sigma-Aldrich; Merck KGaA). The cells were then incubated for $30 \mathrm{~min}$ at $37^{\circ} \mathrm{C}$ prior to analysis using a FACSCalibur flow cytometer (BD Biosciences) and CellQuest software version 3.3 (BD Biosciences).

Cells treated with 0.09 and $0.89 \mathrm{IU} / \mathrm{ml}$ hCG were collected at a density of $1 \times 10^{6}$ per test tube and centrifuged at $250 \mathrm{xg}$ at $4^{\circ} \mathrm{C}$ for $5 \mathrm{~min}$. The supernatant was then discarded and $1 \mathrm{ml} 70 \%$ ethanol was added at $20^{\circ} \mathrm{C}$ to the test tubes, mixed using oscillation, and stored at $-20^{\circ} \mathrm{C}$. The cell samples were then centrifuged at $250 \mathrm{x} \mathrm{g}$ at $4^{\circ} \mathrm{C}$ for $5 \mathrm{~min}$ to remove the 
supernatant for DNA staining. Next, $1 \mathrm{ml}$ DNA staining solution containing $20 \mu \mathrm{l}$ RNase (Thermo Fisher Scientific, Inc.) and $20 \mu \mathrm{l}$ PI (Sigma-Aldrich; Merck KGaA) was added. The cells were then incubated for $30 \mathrm{~min}$ at $37^{\circ} \mathrm{C}$ prior to analysis using a FACSCalibur flow cytometer (BD Biosciences) and CellQuest software version 3.3 (BD Biosciences). All experiments were repeated three times.

Colony formation assay. SGC-7901 cells were cultivated in 6 -well plates at a density of $4 \times 10^{2}$ per well with RPMI-1640 medium at $37^{\circ} \mathrm{C}$ and $5 \% \mathrm{CO}_{2}$. The cells were separated into three groups treated at $37^{\circ} \mathrm{C}$ for 7 days with hCG at concentrations of $0,0.09$ and $0.89 \mathrm{IU} / \mathrm{ml}$. Each group had three repeated experiments for 2 continuous weeks of culture; the cells were then washed twice with PBS, fixed for $30 \mathrm{~min}$ at room temperature with paraformaldehyde, then stained using $10 \mathrm{mg} / \mathrm{ml} \mathrm{Giemsa}$ for $20 \mathrm{~min}$ at room temperature. The number of cell clones was counted by light microscopy (magnification, x100) and the colony formation rate was calculated as follows: Colony formation rate $=$ (colony count/Inoculation cell number) x $100 \%$. All experiments were performed three times.

Western blot analysis. SGC-7901 cells were lysed using RIPA buffer (Pierce; Thermo Fisher Scientific, Inc.) and the total protein was extracted. Protein concentration was determined using a Bio-Rad protein assay system (Bio-Rad Laboratories, Inc., Hercules, CA, USA), according to the manufacturer's protocol. A total of $50 \mathrm{~g}$ protein was separated by $10 \%$ SDS-PAGE, transferred into polyvinylidene difluoride membranes (GE Healthcare, Chicago, IL, USA), and blocked at room temperature for $30 \mathrm{~min}$ in $10 \mathrm{mM}$ Tris-buffered saline containing $0.1 \%(\mathrm{v} / \mathrm{v})$ Tween.20 (TBST) and 5\% (w/v) skimmed milk. The membranes were incubated overnight at $4^{\circ} \mathrm{C}$ with the following primary antibodies at a dilution of 1:1,000. The primary antibodies used in the experiments were: Rabbit GAPDH (cat. no. 2118; Cell Signaling Technology, Inc., Danvers, MA, USA) and c-Met (cat. no. 8198; Cell Signaling Technology, Inc.). Subsequent to washing with TBST, the membranes were incubated with horseradish peroxidase-conjugated sheep anti-rabbit immunoglobulin G (cat. no. 04-15-06 KPL, Inc., Gaithersburg, MD, USA) as a secondary antibody at a dilution of $1: 2,000$ for $1 \mathrm{~h}$ at $37^{\circ} \mathrm{C}$. The membranes were then washed with TBST three times. Membranes were drained of TBST and exposed to the enhanced chemiluminescence (ECL) reagent substrate (Thermo Fisher Scientific, Inc.). Following being allowed to stand undisturbed for $90 \mathrm{sec}$, the membrane was drained of ECL detection reagent. The membrane was wrapped and exposed to X-ray film (Fujifilm, Shanghai, China).

Animal studies. A total of 20 4-week-old male BALB/c nude mice (15 g) were purchased from Vital River Laboratory Animal Technology Co. Ltd., (Beijing, China). Mice were housed in a temperature at $27^{\circ} \mathrm{C}, 50 \%$ relative humidity, alternately exposed to light for $10 \mathrm{~h}$ and without light for $14 \mathrm{~h}$ pathogen-free environment. All mice had free access to food and water. Subcutaneous tumors were generated by subcutaneous injection of $2 \times 10^{6}$ SGC-7901 cells under the right forelimb of each mouse. Tumor growth was observed daily in each group and tumor diameter was measured once a week using calipers. After 7 days, the mice were randomly assigned into 2 groups (10 mice in each group) and treated with or without hCG (890 IU/kg/day) via intraperitoneal injection for 20 consecutive days. The mice in the control group were administrated the $1 \mathrm{ml} / \mathrm{kg} /$ day dimethylsulfoxide. Tumor size was measured and the volume was calculated according to the following formula: Tumor volume $\left(\mathrm{mm}^{3}\right)=\mathrm{d} 2 \times \mathrm{D} / 2$, where $\mathrm{d}$ and $\mathrm{D}$ were the shortest and longest diameter, respectively. At 4 weeks post-injection, the mice were sacrificed, or when the maximum tumor diameter reached $2.0 \mathrm{~cm}$. The tumors were excised and weighed. All animal experiments were approved by the Institution of Animal Care and Use Committee of Sichuan Cancer Hospital.

Statistical analysis. All experiments were repeated three times, and quantitative data were presented as the mean \pm standard deviation. Associations between protein expression and clinicopathological parameters of the patients were assessed using $\chi^{2}$ test. The comparison of mean values between two groups used an unpaired Student's t-test; and data analysis between three groups was performed using one-way analysis of variance with a least significant difference test for post hoc analysis. $\mathrm{P}<0.05$ was considered to indicate a statistically significant difference. All statistical analysis was performed using SPSS13.0 statistical software package (SPSS, Inc., Chicago, IL, USA).

\section{Results}

hCG and hCGR are highly expressed in gastric cancer tissues. The result of immunohistochemical analysis revealed that hCG and hCGR were highly expressed in gastric cancer samples, and were notably higher compared with that of para-carcinoma tissues (Fig. 1). Furthermore, the expression of hCG and hCGR in poorly differentiated gastric cancer was significantly higher compared with that in well/moderately differentiated gastric cancer $(\mathrm{P}<0.01)$, particularly in well/moderately differentiated gastric cancer tissue (Table I).

hCG promotes SGC-7901 cell proliferation. Given that the expression of hCG and hCGR was identified to be highly expressed in poorly differentiated gastric cancer, which is characterized by its high proliferation ability, it was hypothesized that hCG may be involved in the regulation of cell proliferation of gastric cancer. CCK-8 analysis revealed that SGC-7901 cells in the control and hCG-treated groups began to proliferate on day 2 and entered the logarithmic phase on day 3 with a good-state proliferation curve. Cells treated with $0.09 \mathrm{IU} / \mathrm{ml}$ hCG had significantly higher proliferation rate compared with the control group $(\mathrm{P}<0.01)$, and cells treated with $0.89 \mathrm{IU} / \mathrm{ml}$ hCG had a significantly higher cell proliferative ability compared with that of control cells $(\mathrm{P}<0.001)$. All the above indicated that hCG had an effect on the proliferative ability of SGC-7901 cells with concentration ranging from 0.09 to $0.89 \mathrm{IU} / \mathrm{ml}$ in a dose-dependent manner (Fig. 2).

hCG induces cell cycle $G_{2} / M$-phase arrest in SGC-7901 cells. Flow cytometry revealed that hCG is able to promote 
Table I. hCG and hCGR expression in gastric cancer tissues.

\begin{tabular}{|c|c|c|c|c|c|c|c|}
\hline \multirow[b]{2}{*}{ Parameters } & \multirow[b]{2}{*}{$\mathrm{n}$} & \multicolumn{3}{|c|}{$\mathrm{hCG}$} & \multicolumn{3}{|c|}{ hCGR } \\
\hline & & Low & High & P-value & Low & High & P-value \\
\hline All tissues & 62 & 37 & 25 & & 35 & 27 & \\
\hline Age, years & & & & 0.437 & & & 0.796 \\
\hline$<60$ & 31 & 20 & 11 & & 17 & 14 & \\
\hline$\geq 60$ & 31 & 17 & 14 & & 18 & 13 & \\
\hline Sex & & & & 0.960 & & & 0.960 \\
\hline Male & 30 & 18 & 12 & & 16 & 14 & \\
\hline Female & 32 & 19 & 13 & & 19 & 13 & \\
\hline Differentiation grade & & & & $<0.001$ & & & $<0.001$ \\
\hline Well/moderate & 40 & 31 & 9 & & 28 & 12 & \\
\hline Poor & 22 & 6 & 16 & & 7 & 15 & \\
\hline pT & & & & 0.272 & & & 0.960 \\
\hline $\mathrm{T} 1-\mathrm{T} 2$ & 25 & 15 & 10 & & 16 & 13 & \\
\hline $\mathrm{T} 3-\mathrm{T} 4$ & 37 & 20 & 17 & & 19 & 14 & \\
\hline
\end{tabular}

hCG, human chorionic gonadotropin; hCGR, human chorionic gonadotropin receptor; T, tumor stage.
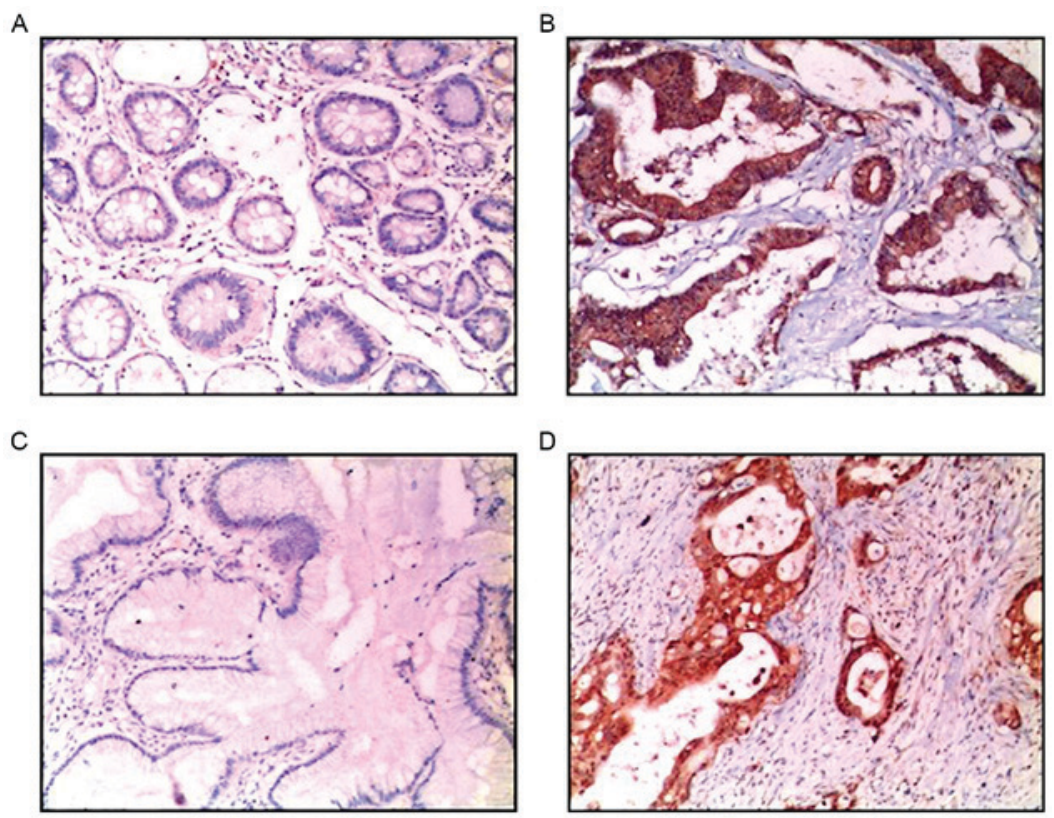

Figure 1. High expression of hCG and hCGR in gastric cancer tissue confirmed by immunohistochemistry. (A) hCG expression in para-carcinoma tissue. (B) hCG expression in gastric cancer tissue. (C) hCGR expression in para-carcinoma tissue. (D) hCGR expression in gastric cancer tissue. hCG, human chorionic gonadotropin; hCGR, human chorionic gonadotropin receptor.

the number of $\mathrm{G}_{2} / \mathrm{M}$ phase cells a compared with control cells (Fig. 3 and Table II).

hCG promotes colony formation abilities of SGC-7901 cells. Results of a colony formation assay revealed that with the increase of hCG concentration, there was a significantly increased number of colonies formed on the plates compared with the control group. hCG treatment at a concentration of $0.09 \mathrm{IU} / \mathrm{ml}$ significantly increased the colony formation rate by $\sim 1.95 \pm 0.12(\mathrm{P}<0.01)$ and $\mathrm{hCG}$ at $0.89 \mathrm{IU} / \mathrm{ml}$ significantly increased the clone formation rate by $\sim 2.88 \pm 0.20$ compared with the control group ( $\mathrm{P}<0.01$; Fig. 4).

hCG promotes the expression of c-Met in SGC-7901 cells. With the increase of hCG concentration, $\mathrm{hCG}$ promoted the protein expression of c-Met in a dose-dependent manner in SGC-7901 cells (Fig. 5A). Further experiments which used an inhibitor PKAI to block the PKA signaling pathway demonstrated that once the PKA signaling pathway was blocked, it inhibited the increased activation of c-Met expression that resulted from 
Table II. Dose-dependent effect of hCG on the cell cycle of SGC-7901 cells.

\begin{tabular}{lrrr}
\hline & \multicolumn{3}{c}{$h C G, \mathrm{IU} / \mathrm{ml}$} \\
\cline { 2 - 4 } Cell cycle phase & \multicolumn{1}{c}{0} & 0.09 & 0.89 \\
\hline $\mathrm{G}_{0} / \mathrm{G}_{1}$ & 85.1 & 76.6 & 68.2 \\
$\mathrm{~S}$ & 3.6 & 3.3 & 8.0 \\
$\mathrm{G}_{2} / \mathrm{M}$ & 11.2 & 20.0 & 23.7 \\
\hline
\end{tabular}

Values indicate the proportion of cells in each cell cycle phase (\%). hCG, human chorionic gonadotropin.

hCG treatment (Fig. 5B). The above results revealed that hCG is able to promote the expression of c-Met in SGC-7901 cells, which relies on the PKA signaling pathway.

hCG promotes tumor growth in vivo. The role of hCG in promoting cell proliferation, as presented in Fig. 2, indicate that hCG may function as an activator in carcinogenesis. To determine the contribution of hCG to cancer pathogenesis, well-established in vivo grafting models of experimental gastric cancer were established, which were randomly assigned into 2 groups and treated with or without hCG $(890 \mathrm{IU} / \mathrm{kg} /$ day $)$ via intraperitoneal injection for 20 consecutive days. At the end of the study, the nude mouse transplantation tumor experiment revealed that the tumors of the mice in the hCG-treated group were significantly larger compared with that of the control group $(\mathrm{P}<0.001$; Fig. 6). This result indicates that $\mathrm{hCG}$ serves a key role in promoting tumor growth.

\section{Discussion}

At present, accumulated evidence demonstrates that hCG is associated with the cell differentiation and the metastasis of gastric cancer $(23,24)$, however, its mechanism in gastric cancer development remains largely unknown. Further study of the biological effect of hCG in gastric cancer will broaden current understanding of the development process of gastric cancer and allow for earlier and more effective endocrine therapy. In the present study, it was demonstrated that hCG and its receptor had abnormally high expression in gastric cancer tissues, and that hCG promoted cell proliferation by activating the expression of c-Met, which relied on the PKA signaling pathway.

The affinity and capacity of hCGR expressed in gastric cancer tissue are higher compared with that in normal gastric mucosa with radioactive ligand labeling (25). In the present study, it was also confirmed that the positive rate of hCG and hCGR expressed in gastric cancer tissue was higher compared with that of para-carcinoma tissues, suggesting that hCG and hCGR were potential diagnostic markers of gastric cancer.

Through further experimental analysis, it was demonstrated that hCG at the low concentration of $0.09 \mathrm{IU} / \mathrm{ml}$ was able to serve a role in promoting cell proliferation as an oncogene. $\mathrm{hCG}$ promotes lymphocyte proliferation in a dose-dependent manner in physiological conditions (26). hCG at $0.1 \mathrm{IU} / \mathrm{ml}$

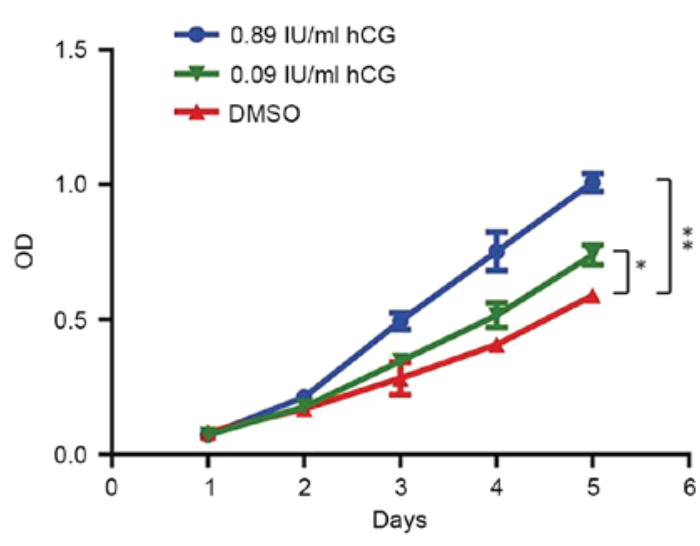

Figure 2. SGC-7901 cell proliferation increased by hCG. Cells at a density of $2 \times 10^{3}$ cells per well in 96-well plates were cultured for 5 days with hCG at concentration of $0,0.09$ and $0.89 \mathrm{IU} / \mathrm{ml}$. Cell proliferation was measured at $450 \mathrm{~nm}$ using a plate reader using following treatment with cell counting kit-8 dye. Data represent the mean \pm SD of 3 experiments at each concentration. ${ }^{*} \mathrm{P}<0.01$ and ${ }^{* *} \mathrm{P}<0.001$ with comparisons shown by lines. hCG, human chorionic gonadotropin; DMSO, dimethylsulfoxide.

is able to promote the cell proliferation of Leydig cells and granulosa cells $(9,27)$, and hCG stimulates myometrium cell growth at a concentration of $3 \mathrm{nmol} / \mathrm{l}(28)$. The concentration of hCG in serum at the early stages of pregnancy is as high as $160 \mathrm{IU} / \mathrm{ml}$, and is maintained at $\sim 10 \mathrm{IU} / \mathrm{ml}$ in serum in the middle-late stages, finally disappearing rapidly postpartum (29). If no hCG residue is present in the placenta, the hCG serum concentration falls to $1 \mathrm{IU} / \mathrm{ml} 4$ days postpartum, and cannot be detected after 9 days (30). Based on these results, hCG concentration should be $<1 \mathrm{IU} / \mathrm{ml}$ under normal physiological conditions.

The effect of hCG on cell growth is achieved through luteinizing hormone/hCGR (31). Ala-Fossi et al (32) revealed that the effect of hCG on cell growth depends on its receptor, and in ovarian epithelial carcinoma cell lines without hCGR expression, it neither promotes cell growth nor alters the expression of growth-associated factors. In the present study, it was also revealed that the high ectopic expression of hCG in gastric cancer tissue was accompanied by the high expression of hCGR, suggesting that hCG served the role of proto-oncogene, which relied on its receptor signal transduction.

Growth factors in serum may potentially stimulate the expression of genes in cells; for example, epidermal growth factor is able to upregulate multiple genes including c-Fos, c-Jun and c-Myc (33-35), serum-free culture was used to establish cells in their resting state, maintaining gene and cytokine levels in the cells at a physiological level. When exposed to exogenous stimuli, the effect of cell growth may be started or inhibited. The number of cells at the $S$ and $G_{2} / M$ phase were increased, with a corresponding loss of cells at the $\mathrm{G}_{0} / \mathrm{G}_{1}$ phase, an increased PI value and increased DNA synthesis, cell division and decreased static cells. Kim et al (36) treated granulosa cells with hCG for 3 days, and the number of cells at the $\mathrm{S}$ and $\mathrm{G}_{2} / \mathrm{M}$ phase were significantly higher compared with untreated cells.

Numerous experiments in vitro and in vivo have revealed that hCG effects the expression of oncogenes including c-Fos (37), c-Jun (38) and c-Myc (39) in a time- and dose-dependent manner. The experimental results of the present study were 

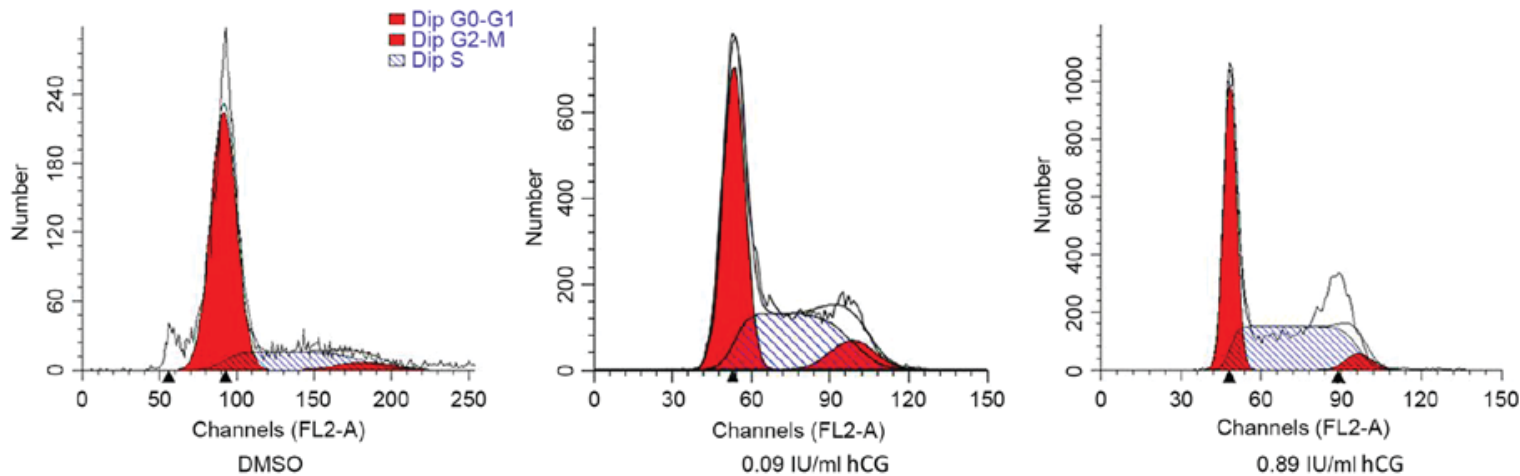

Figure 3. Increased cell number of SGC-7901 cells at the $\mathrm{G}_{2} / \mathrm{M}$ stage as a result of treatment with hCG. Representative images of cell cycle assays using flow cytometry in SGC-7901 cells with hCG at concentrations of 0, 0.09 and $0.89 \mathrm{IU} / \mathrm{ml}$. Data represent the mean \pm SD of 3 experiments at each concentration. hCG, human chorionic gonadotropin; DMSO, dimethylsulfoxide.

A

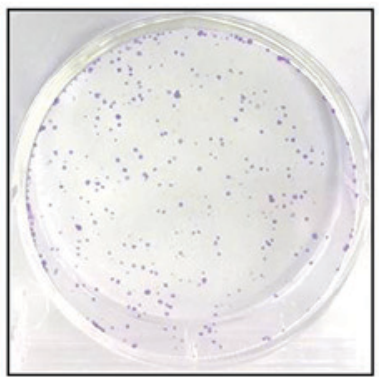

DMSO

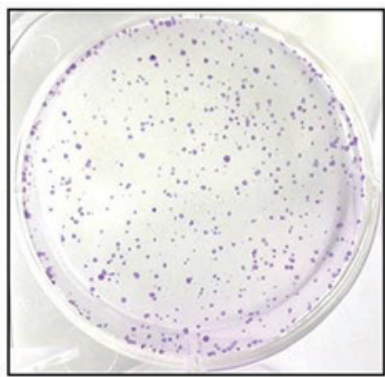

$0.09 \mathrm{IU} / \mathrm{mLhCG}$

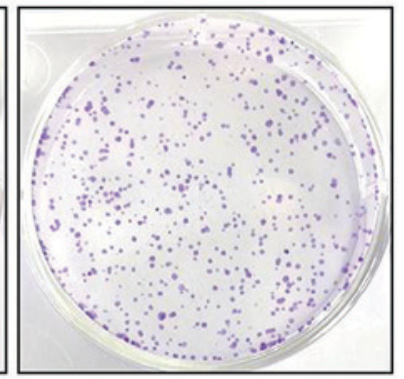

$0.89 \mathrm{IU} / \mathrm{mLhCG}$

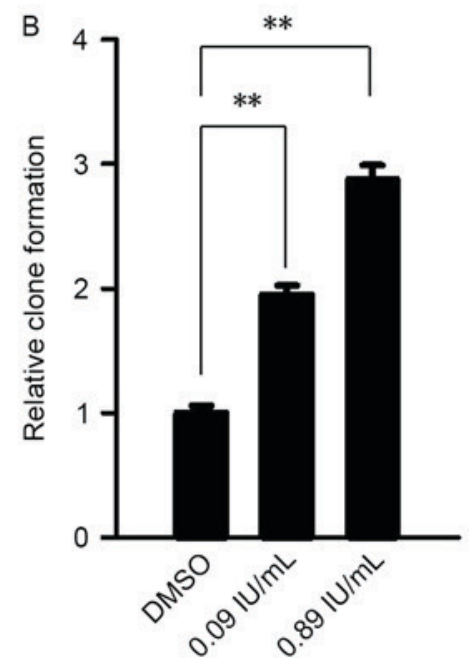

Figure 4. Promotion of SGC-7901 cell colony formation ability following hCG treatment. (A) Colony formation assay (Left, control group; middle, 0.09 IU/ml hCG treatment group; right, $0.89 \mathrm{IU} / \mathrm{ml}$ hCG treatment group). (B) Quantitative analysis of the colony formation assay. Data represent the mean $\pm \mathrm{SD}$ of 3 experiments at each concentration. ${ }^{* *} \mathrm{P}<0.01$ with comparisons shown by lines. $\mathrm{hCG}$, human chorionic gonadotropin; DMSO, dimethylsulfoxide.

A

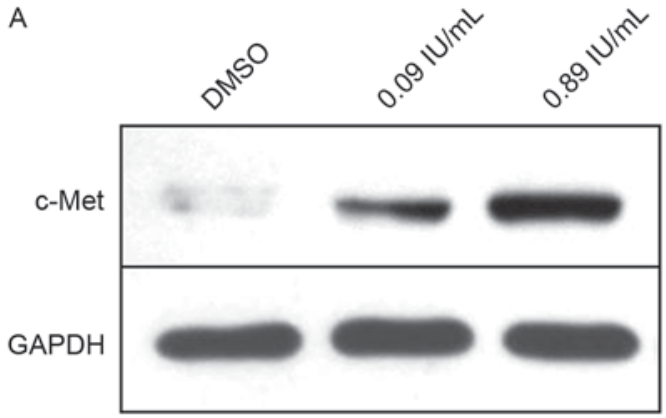

B

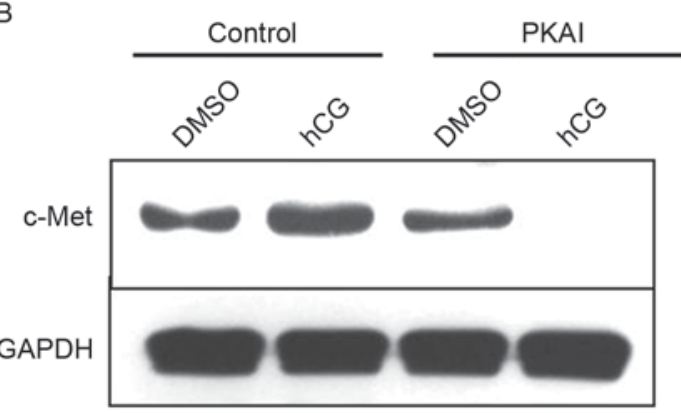

Figure 5. Increased expression of c-Met promoted by hCG relies on the protein kinase A signaling pathway. (A) Detection of the protein expression of c-Met following hCG exposure using western blot analysis. (B) Analysis of the protein expression of c-Met following PKAI treatment using western blot analysis. Data represent the mean \pm SD of 3 experiments at each concentration. GAPDH was used as the reference gene. c-Met, hepatocyte growth factor transmembrane protein receptor; PKAI, protein kinase A inhibitor; hCG, human chorionic gonadotropin; DMSO, dimethylsulfoxide.

in conformity with these previous studies, and the activation of c-Met by hCG in gastric cancer cells should be considered a physiological phenomenon. The PKA signaling pathway mainly promotes cell proliferation (5). In the present study, it was also demonstrated that the ability of hCG to promote cell proliferation depended on the PKA signaling pathway. These results suggested that hCG may be one of the initial factors for the expression of c-Fos, c-Jun and c-Myc in gastric cancer. Therefore, hCG promotes the process of gastric cancer and tumor metastasis through inducing the expression of c-Met. 
A

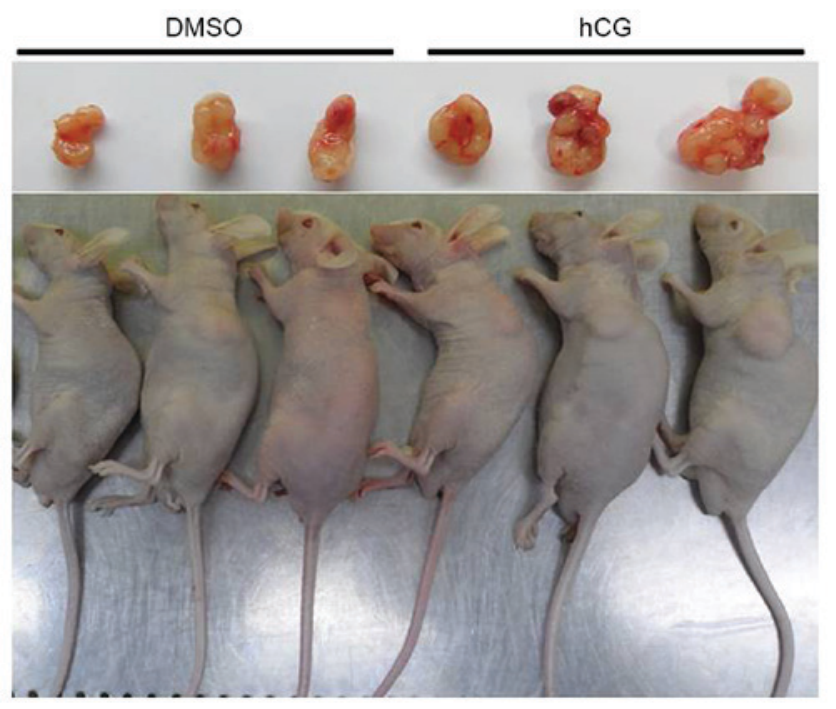

B

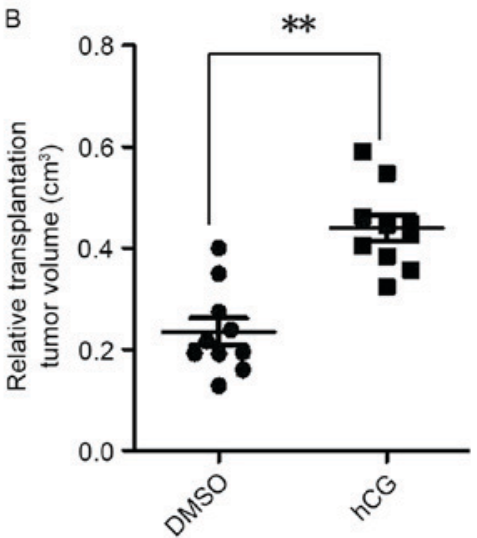

C

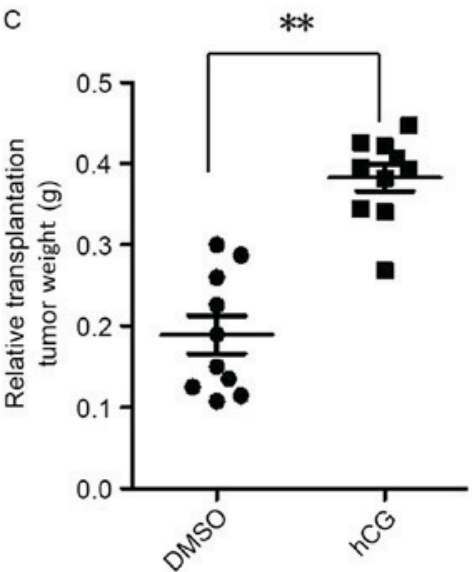

Figure 6. Increased tumor growth in response to hCG treatment in vivo. Nude mice bearing SGC-7901 cancer cells were treated with or without hCG (890 IU/kg/day) via intraperitoneal injection for 20 consecutive days. (A) Images of nude mice and the tumors. (B) Relative transplantation tumor volume. (C) Relative transplantation tumor weight. Data represent the mean $\pm \mathrm{SD}$ of 3 experiments at each concentration. ${ }^{* *} \mathrm{P}<0.01$ with comparisons shown by lines. hCG, human chorionic gonadotropin; DMSO, dimethylsulfoxide.

In conclusion, the present study confirmed that hCG and its receptor had high expression in gastric cancer tissue, and hCG activated the expression of c-Met through its receptor and the PKA signaling pathway to promote gastric cancer cell proliferation. The present study further revealed the potential function of hCG in the development of gastric cancer, suggesting that hCG may be a molecular marker in the early diagnosis of gastric cancer, in addition to being a potential drug target for treatment of gastric cancer.

\section{Acknowledgements}

The authors would like to thank the Experimental Animal Center of West China Center of Medical Sciences (Chengdu, China) for animal feeding.

\section{Funding}

The present study was supported by grants from the National Natural Science Foundation of China (grant no. 81502075), the Foundation of Science and Technology of Sichuan Province (grant nos. 2014JY0136, 2014JY0017 and 2015FZ0072), the Foundation of Science and Technology of Chengdu City (grant nos. 2015-HM01-00141-SF, 2015-HM01-00143-SF and 2015-HM01-00139-SF).

\section{Availability of data and materials}

All data generated or analyzed during the present study are included in this published article.

\section{Authors' contributions}

RZ and TZ collected clinical tissues. WX, XS, LZ and YG performed the in vitro experiments. $\mathrm{CZ}$ and $\mathrm{YB}$ designed the study and revised the manuscript.

\section{Ethics approval and consent to participate}

The present study was approved by the Ethics Committee of Sichuan Cancer Hospital (Chengdu, China). Written informed consent was obtained from all patients.

\section{Patient consent for publication}

Written informed consents for the publication of this data were obtained from all patients in the present study.

\section{Competing interests}

The authors declare that they have no competing interests. 


\section{References}

1. Richards JS, Fitzpatrick SL, Clemens JW, Morris JK, Alliston T and Sirois J: Ovarian cell differentiation: A cascade of multiple hormones, cellular signals, and regulated genes. Recent Prog Horm Res 50: 223-254, 1995.

2. Parrott JA, Doraiswamy V, Kim G, Mosher R and Skinner MK Expression and actions of both the follicle stimulating hormone receptor and the luteinizing hormone receptor in normal ovarian surface epithelium and ovarian cancer. Mol Cell Endocrinol 172 213-222, 2001.

3. Yang Y, Adachi K, Sheridan MA, Alexenko AP, Schust DJ, Schulz LC, Ezashi T and Roberts RM: Heightened potency of human pluripotent stem cell lines created by transient BMP4 exposure. Proc Natl Acad Sci USA 112: E2337-E2346, 2015.

4. Cole LA and Butler S: Hyperglycosylated hCG, hCG $\beta$ and Hyperglycosylated hCG $\beta$ : Interchangeable cancer promoters. Mol Cell Endocrinol 349: 232-238, 2012.

5. Yaron Y, Schwartz D, Evans MI, Aloni R, Kapon A and Rotter V: p53 tumor suppressor gene expression in the mouse ovary during an artificially induced ovulatory cycle. J Reprod Med 44 107-114, 1999.

6. Hastings JM, Jackson KS, Mavrogianis PA and Fazleabas AT: The estrogen early response gene FOS is altered in a baboon model of endometriosis. Biol Reprod 75: 176-182, 2006.

7. Yuri T, Kinoshita Y, Emoto Y, Yoshizawa K and Tsubura A: Human chorionic gonadotropin suppresses human breast cancer cell growth directly via p53-mediated mitochondrial apoptotic pathway and indirectly via ovarian steroid secretion. Anticancer Res 34: 1347-1354, 2014.

8. Devi GR, Oldenkamp JR, London CA and Iversen PL: Inhibition of human chorionic gonadotropin beta-subunit modulates the mitogenic effect of c-myc in human prostate cancer cells Prostate 53: 200-210, 2002.

9. Mori Sequeiros Garcia M, Gomez NV, Gorostizaga A, Acquier A, Gonzalez-Calvar SI, Mendez CF and Paz C: MAP kinase phosphatase-3 (MKP-3) is transcriptionally and post-translationally up-regulated by hCG and modulates cAMP-induced p21 expression in MA-10 Leydig cells. Mol Cell Endocrinol 371: 174-181, 2013.

10. Maheshwari A, Misro MM, Aggarwal A and Sharma RK: $\mathrm{N}$-acetyl-L-cysteine modulates multiple signaling pathways to rescue male germ cells from apoptosis induced by chronic hCG administration to rats. Apoptosis 17: 551-565, 2012.

11. Jiang X, Russo IH and Russo J: Human chorionic gonadotropin and inhibin induce histone acetylation in human breast epithelial cells. Int J Oncol 20: 77-79, 2002.

12. Dricu A, Sergiu-Bogdan C, Brismar K, Biberfeld P and Andersson LC: A synthetic peptide derived from the human eosinophil-derived neurotoxin induces apoptosis in Kaposi's sarcoma cells. Anticancer Res 24: 1427-1432, 2004

13. De Vita F, Di Martino N, Fabozzi A, Laterza MM, Ventriglia J, Savastano B, Petrillo A, Gambardella V, Sforza V, Marano L, et al Clinical management of advanced gastric cancer: The role of new molecular drugs. World J Gastroenterol 20: 14537-14558, 2014.

14. Liang L, Fang JY and Xu J: Gastric cancer and gene copy number variation: Emerging cancer drivers for targeted therapy. Oncogene 35: 1475-1482, 2016.

15. Kidd M, Gustafsson B and Modlin IM: Gastric carcinoids (neuroendocrine neoplasms). Gastroenterol Clin North Am 42: 381-397, 2013.

16. Arai O, Kakutani A, Mouri H, Ikeda H, Notohara K and Matsueda K: A case of advanced gastric cancer growing extramurally with gynecomastia and high hCG-beta serum level. Gan To Kagaku Ryoho 37: 1369-1372, 2010 (In Japanese).

17. Ohi S, Takahashi N, Hashimoto H, Tachibana T, Hirabayashi T, Sugiyama K, Yanaga K and Ishikawa H: Establishment and characterization of an IGSK-2 cell line derived from ascitic fluid of recurrent hCG and somatostatin secreted adenocarcinoma of the stomach. Hum Cell 20: 52-61, 2007.

18. Gholamin S, Fiuji H, Maftouh M, Mirhafez R, Shandiz FH and Avan A: Targeting c-MET/HGF signaling pathway in upper gastrointestinal cancers: Rationale and progress. Curr Drug Targets 15: 1302-1311, 2014.

19. Boccaccio C and Comoglio PM: The MET oncogene in glioblastoma stem cells: Implications as a diagnostic marker and a therapeutic target. Cancer Res 73: 3193-3199, 2013.
20. Noguchi E, Saito N, Kobayashi M and Kameoka S: Clinical significance of hepatocyte growth factor/c-Met expression in the assessment of gastric cancer progression. Mol Med Rep 11: 3423-3431, 2015

21. Marano L, Chiari R, Fabozzi A, De Vita F, Boccardi V, Roviello G, Petrioli R, Marrelli D, Roviello F and Patriti A: c-Met targeting in advanced gastric cancer: An open challenge. Cancer Lett 365: 30-36, 2015.

22. Edge SB and Compton CC: The american joint committee on cancer: The 7th edition of the AJCC cancer staging manual and the future of TNM. Ann Surg Oncol 17: 1471-1474, 2010.

23. Zhang W, Yang H and Han S: The effect of ectopic HCG on microvessel density in gastric carcinoma. Zhonghua Zhong Liu Za Zhi 20: 351-353, 1998 (In Chinese)

24. Ohdaira H, Murai R, Hanyu N, Abe M and Yanaga K: Gastric cancer producing AFP/HCG which had a rapidly progressive course with metastasis to the brain discovered postoperatively. Nihon Shokakibyo Gakkai Zasshi 104: 666-670, 2007.

25. Rindi G, Luinetti O, Cornaggia M, Capella C and Solcia E: Three subtypes of gastric argyrophil carcinoid and the gastric neuroendocrine carcinoma: A clinicopathologic study. Gastroenterology 104: 994-1006, 1993.

26. Bansal AS, Bora SA, Saso S, Smith JR, Johnson MR and Thum MY: Mechanism of human chorionic gonadotrophin-mediated immunomodulation in pregnancy. Expert Rev Clin Immunol 8: 747-753, 2012.

27. Goto M, Iwase A, Harata T, Takigawa S, Suzuki K, Manabe S and Kikkawa F: IGF1-induced AKT phosphorylation and cell proliferation are suppressed with the increase in PTEN during luteinization in human granulosa cells. Reproduction 137: 835-842, 2009

28. Horiuchi A, Nikaido T, Yoshizawa T, Itoh K, Kobayashi Y, Toki T, Konishi I and Fujii S: HCG promotes proliferation of uterine leiomyomal cells more strongly than that of myometrial smooth muscle cells in vitro. Mol Hum Reprod 6: 523-528, 2000.

29. Ayiasi RM, Muhumuza C, Bukenya J and Orach CG: The effect of prenatal counselling on postpartum family planning use among early postpartum women in masindi and kiryandongo districts, uganda. Pan Afr Med J 21: 138, 2015.

30. Fantz CR, Dagogo-Jack S, Ladenson JH and Gronowski AM: Thyroid function during pregnancy. Clin Chem 45: 2250-2258, 1999.

31. Ziecik AJ, Kaczmarek MM, Blitek A, Kowalczyk AE, Li X and Rahman NA: Novel biological and possible applicable roles of LH/hCG receptor. Mol Cell Endocrinol 269: 51-60, 2007.

32. Ala-Fossi SL, Grenman S, Zhang FP, Blauer M, Punnonen R and Maenpaa J: Ovarian cancer and gonadotropins in vitro: New evidence in favor of independence. Anticancer Res 19: 4289-4295, 1999.

33. Willmarth NE and Ethier SP: Amphiregulin as a novel target for breast cancer therapy. J Mammary Gland Biol Neoplasia 13: 171-179, 2008.

34. Lin JK: Molecular targets of curcumin. Adv Exp Med Biol 595: 227-243, 2007

35. Puzianowska-Kuznicka M, Pietrzak M, Turowska $\mathrm{O}$ and Nauman A: Thyroid hormones and their receptors in the regulation of cell proliferation. Acta Biochim Pol 53: 641-650, 2006.

36. Kim JM, Yoon YD and Tsang BK: Involvement of the fas/fas ligand system in p53-mediated granulosa cell apoptosis during follicular development and atresia. Endocrinology 140: 2307-2317, 1999.

37. Dos Santos E, Dieudonne MN, Leneveu MC, Pecquery R, Serazin V and Giudicelli Y: In vitro effects of chorionic gonadotropin hormone on human adipose development. J Endocrinol 194: 313-325, 2007.

38. Yuan S, Xu S, Yang X, Liu X, Hao J and Qian M: Effects of c-jun on hCG-induced testosterone secretion of rat Leydig cells in vitro. Zhonghua Nan Ke Xue 10: 345-347, 350, 2004 (In Chinese).

39. Russo IH and Russo J: Hormonal approach to breast cancer prevention. J Cell Biochem Suppl 34: 1-6, 2000.

This work is licensed under a Creative Commons Attribution-NonCommercial-NoDerivatives 4.0 International (CC BY-NC-ND 4.0) License. 